\title{
超音波流量計の流れ場
}

高宮敏行O，伊藤茂行（リコーエレメックス(株)），大島裕子（(株）リコー）

\section{Flow Field of Ultrasonic Flow Meter}

\author{
Toshiyuki TAKAMIYA, Shigeyuki ITO and Yuko OSHIMA
}

\begin{abstract}
Basic principle of ultrasonic flow meters is to measure the traveling time difference of ultrasonic wave between the go and back signals traveling through gas flows. The flow fields are one of the most important factors of the meter quality together with the sensors and the electronic systems. That is, the signal to the noise ratio of the sensor depends on the flow condition of the passage of ultrasonic wave. Typical ultrasonic flow meters are analyzed from the viewpoint of fluid dynamics, using hot-wire anemometry, visualization with PIV method and numerical simulation. The flow fields with low turbulence level are required for meter.
\end{abstract}

Keywords: Ultrasonic flow meter, Visualization, Hydrogen bubble method, PIV, Simulation

1.はじめに

超音波流量計法気流の流れに重畺した超音波の往路と 復路の二つのセンサによる時間差によって流速を知り， 流量換算して積算值を表示する装置である．超音波セン サの相対的な位置によって種々の型の流量計が考えられ， センサが直線的に流路に相対する I 型，流路壁面で 1 度 反射する $\mathrm{V}$ 型， 2 度反射する $\mathrm{W}$ 型などがある. 流量計と しては，流路形状・センサ感度・電子回路・システム等 の総合的な性能に依存するが，ここでは超音波の伝達が 流れに大きく影響されることを考えて流体力学的な観点 から考察を行った．水を用いての水素気泡法による可視 化及びその画像の PIV 解析, 熱線流速計による空気での 流速と乱流の計測およびシミュレーションを行った．流 れの中で放たれた超音波信号の順方向と逆方向の時間を 流量に対して計測した例およびその時間差を示したのが Fig. 1 で, 時間差が流量と線形関係であることが示されて いる.

\section{2. 実験装置及び方法}

実験モデル：実験のモデルは $180(\mathrm{~W}) \times 155(\mathrm{H}) \times$ 60 (D) $\mathrm{mm}$ mアクリル製で可視化と計測に使用した. 超音波が通過する流路断面は I 型の $30 \times 6 \mathrm{~mm}$ と同断面 積で扁平な $\mathrm{V}$ 型の $20 \times 9 \mathrm{~mm}$ m 2 種である. I 型の図を Fig. 2 にV 型のモデルの写真をFig. 3 に示す.

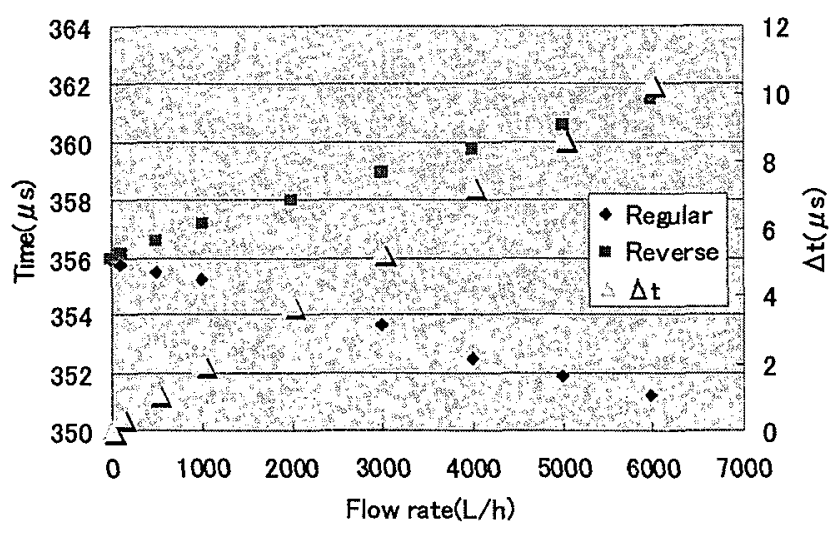

Fig. 1 Relation between flow rate and time of ultrasonic wave.

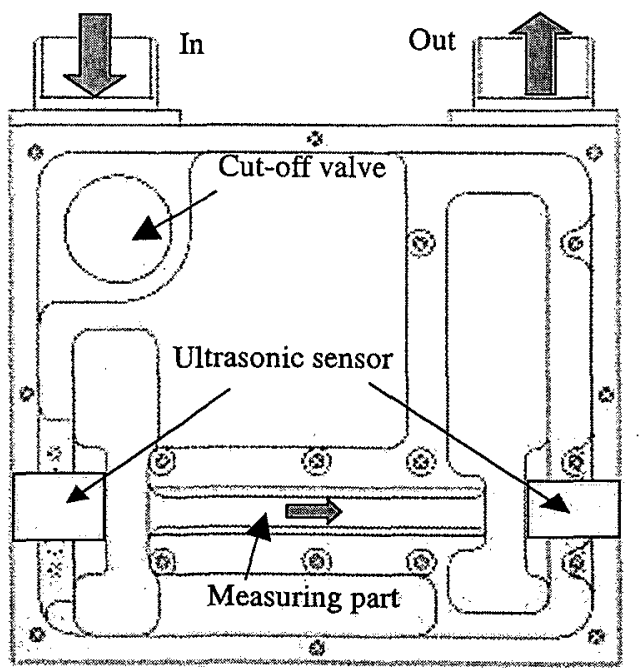

Fig. 2 I-type meter. 


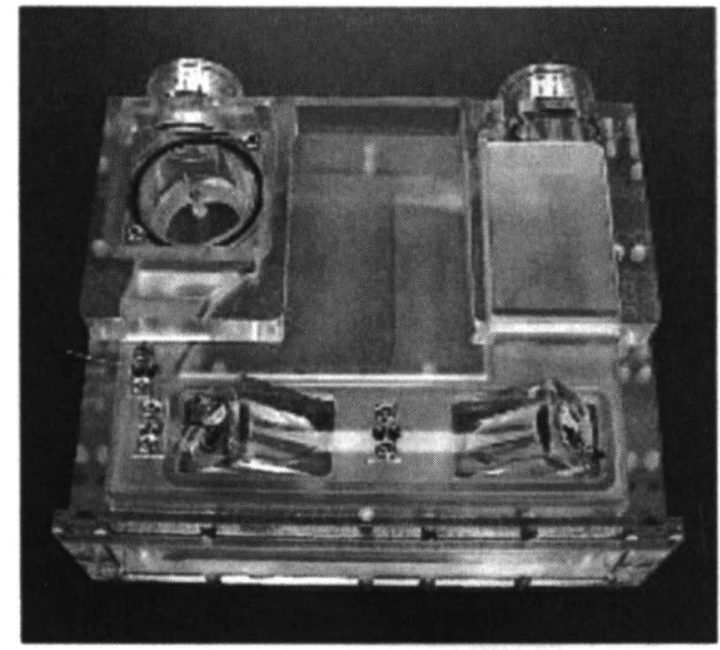

Fig. 3 Acrylic model of V-type meter for visualization.

水供給：上部に設置した水槽で水位を一定とし, 下流側 に別にタンクを設けて, ポンプでくみ上げて循環させた. 流量はメータの下流に設けた大，中，小のバルブによっ て調節した。なお，メータの下流に直列に基準メータを 設置して，流量はそれにより定めた.

水素気泡法：流量計の流入管路の少し上流にシリコン栓 を挿入，その栓に電線を通し，流量計流入口付近にステ ンレス板の陽極とステンレス網の陰極を近接して設置し た.Fig. 4 に示すように両極間に $400 \mathrm{~V}$ をかけることで陰 極から水素気泡が発生し, 流量計内部に流れ込む.
可視化：可視化装置の概略を Fig. 5 に示す. 水素気泡法 の場合は照明が重要で,メータ内部の各断層の観察をす るためにアルゴンレーザのシート光出射部を $\mathrm{X} \cdot \mathrm{Z}$ パルス ステージに固定し, PCによって自動的に移動するように した. 水平方向の像を得るには, メータ側面に水平なレ ーザーシート光を照射して,メータ下部に置いた 45 度に 傾けた鏡を用いて撮影するが, 垂直断面の像の場合, こ れとは逆に鏡を通してメータ底面に垂直にレーザーシー ト光を照射しメータ側面から撮影した. これらの像はデ イジタルビデオ及び高速度カメラに収録し, 解析に用い られた。

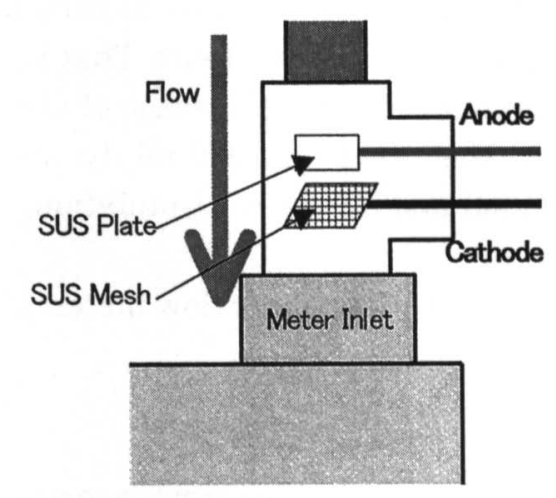

Fig. 4 Hydrogen bubble generator.

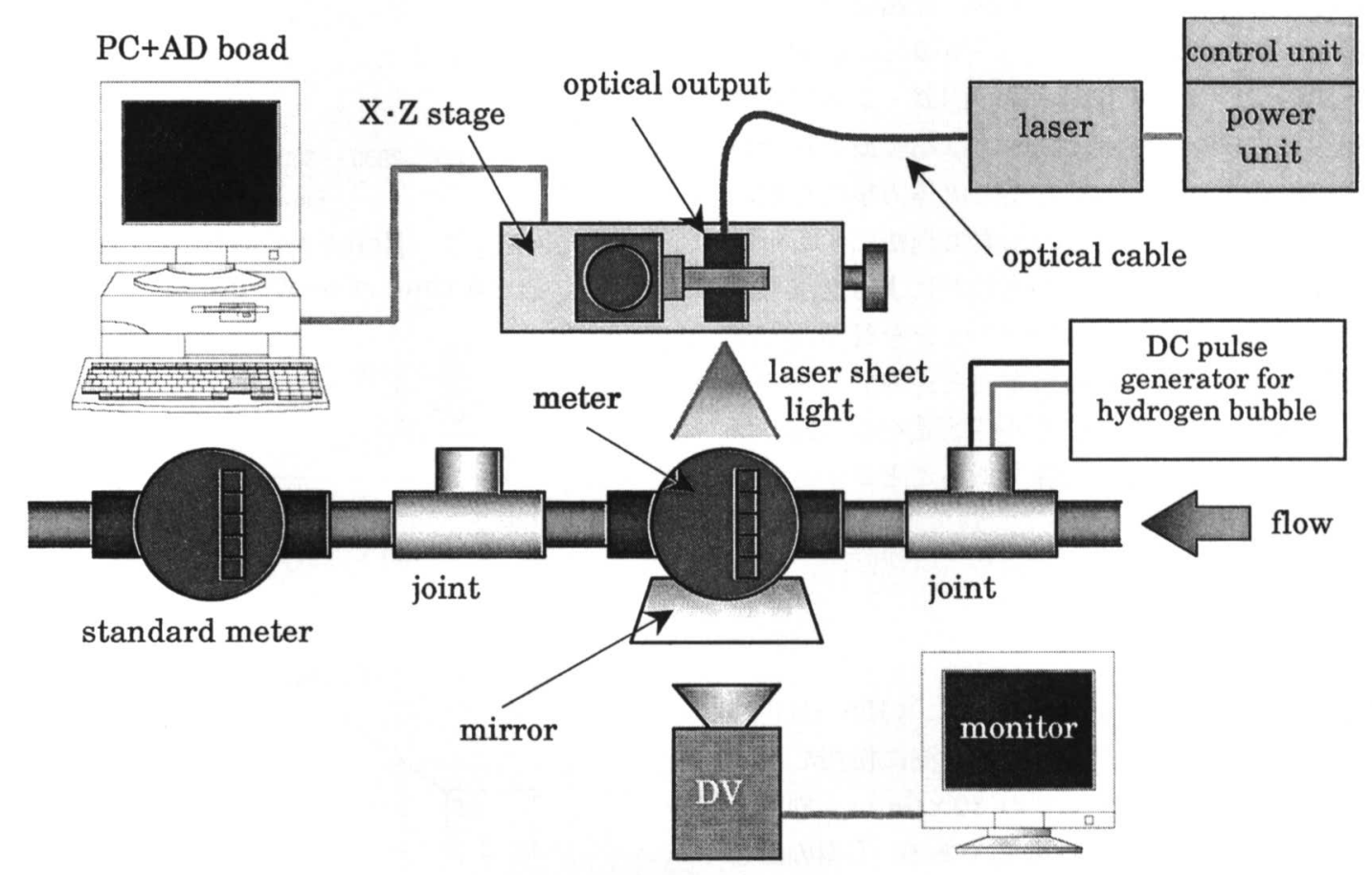

Fig. 5 Schematic diagram of the image capturing. 


\section{3. 結果及び考察}

\section{1 可視化}

I 型メータについて水平面と垂直面の可視化された画 像の例を Fig. 6 および 7 に示す. 流路に螺旋状の流れと 端部における渦の生成が観測される. 渦の生成と乱流強 度を減少させるために，滑らかに接続する流路をもった $\mathrm{V}$ 型メータについての可視化画像とその PIV 解析を行っ たのが Fig. 8 および 9 で，速度べクトルを矢印で示して ある．超音波が通過する計測部分でも影による誤差べク トルを除けばスムースな流れが実現されている.

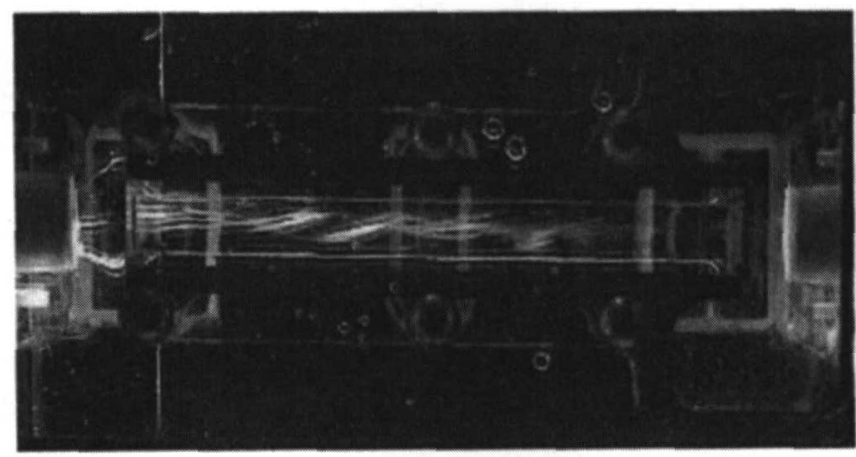

Fig. 6 Visualized flow pattern in the horizontal plane of I-type meter at the flow rate of $100 \mathrm{~L} / \mathrm{H}$.

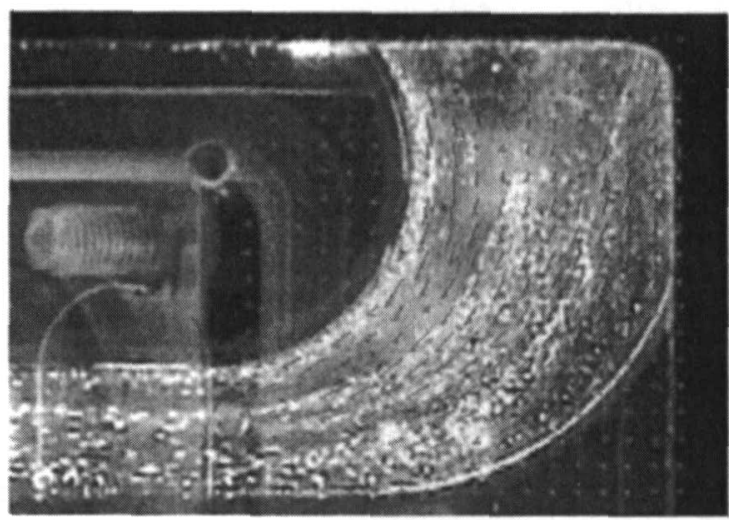

Fig. 8 Flow field near the entrance part of V-type meter. Arrows show the velocity vectors by PIV.

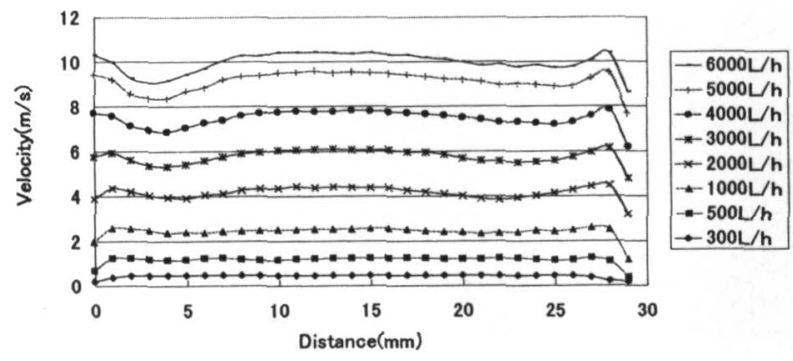

Fig. 10 Velocity distribution of the central part of I-type meter.

\section{2 熱線流速計による計測}

種々の流量について熱線流速計による平均速度と乱流 強度を I 型メータについて Fig. 10 および 11 に，V 型メ 一タについて Fig. 12 および 13 に示す.ささらに, V 型メ ータの流路にハネカムを入れた場合の計測を Fig. 14 お び 15 に示す. 八ネカムによって高流量でも境界面を除い て $5 \%$ 以下に乱流が抑えられ平坦な分布が得られた。

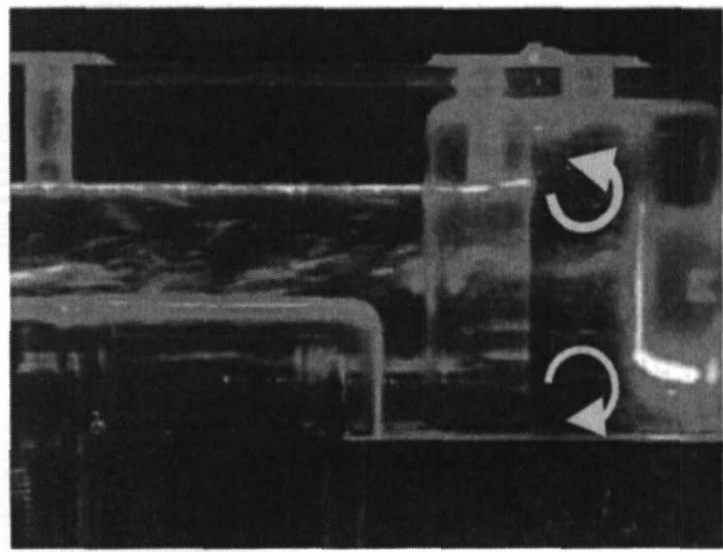

Fig. 7 Two vortices are observed at the edge part near the sensor in the vertical plane.

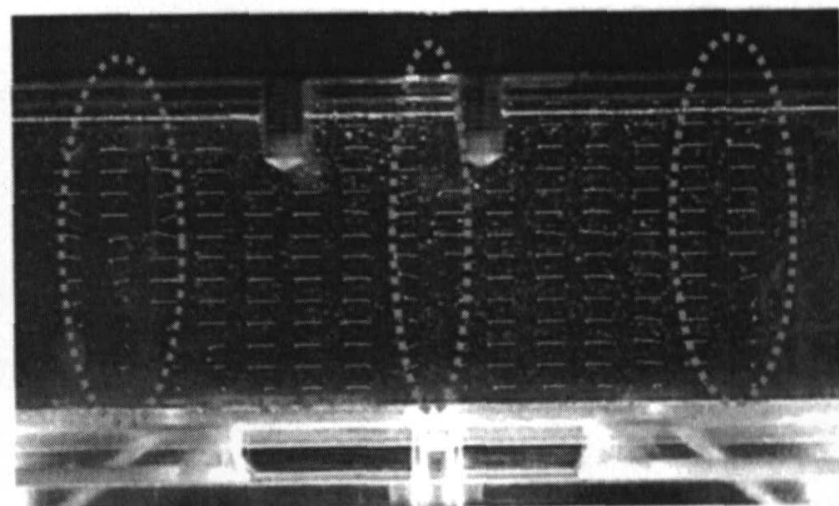

Fig. 9 Velocity vectors at the central part.

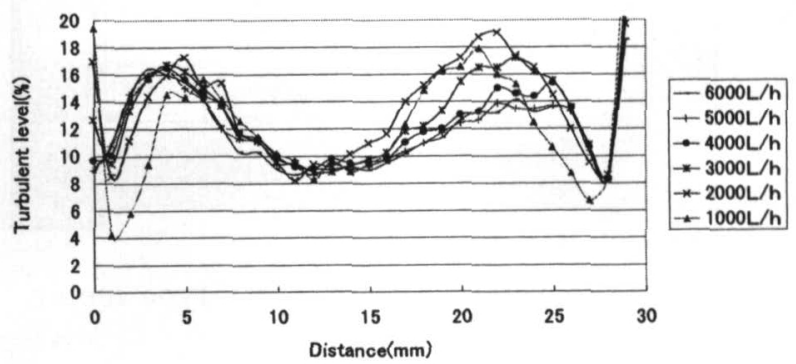

Fig. 11 Turbulent level of I-type meter. 


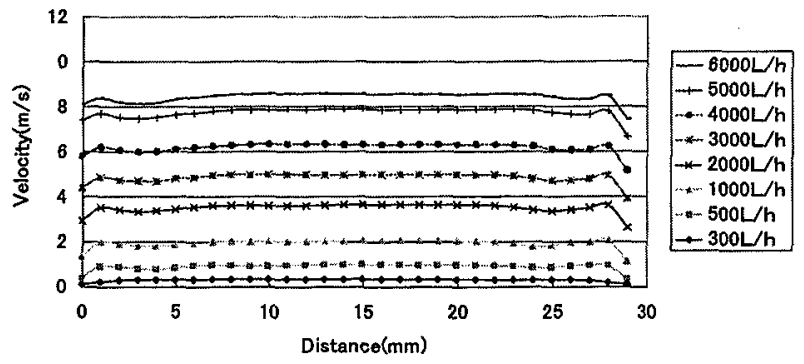

Fig. 12 Velocity distribution of V-type meter.

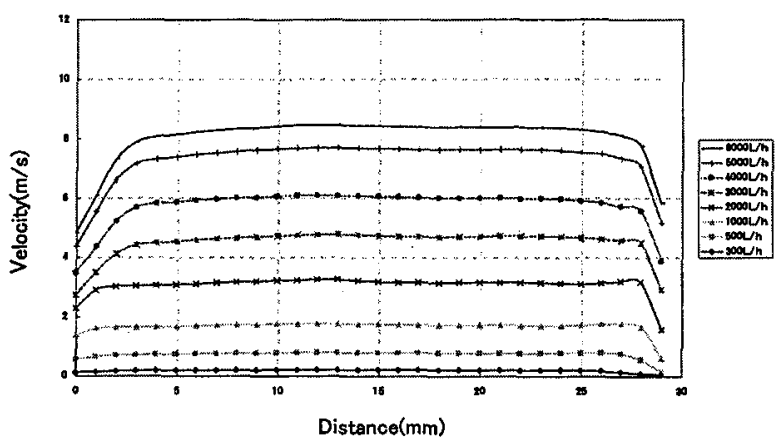

Fig. 14 Velocity distribution of V-type meter with small honeycomb at the entrance part.

\section{3 数値シミュレーション}

I 型およびその変形や $\mathrm{V}$ 型メータの数值シミュレーシ ヨンを行った. V 型メータの速度ベクトルをFig. 16 に示 す。低速度部分がセンサ插入によって起こるが，ほぼ一 様の流れが期待される.

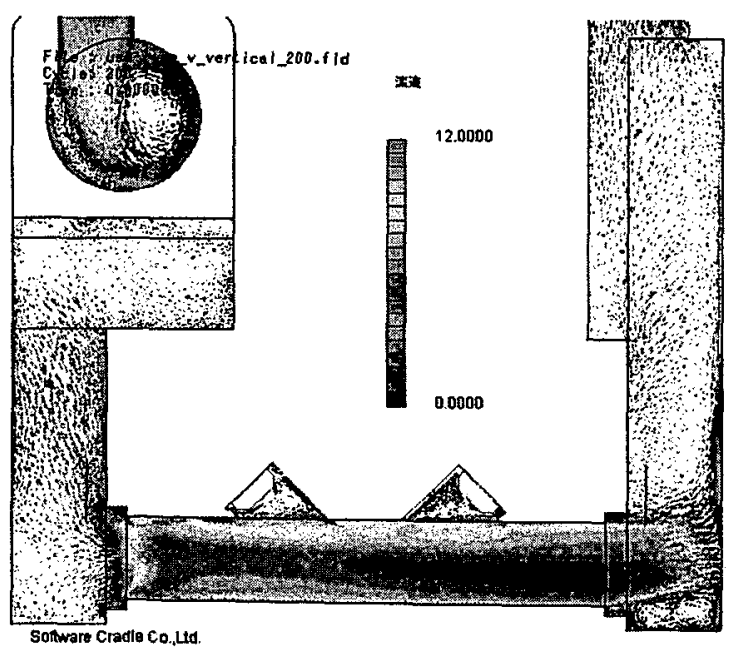

Fig. 16 Velocity vectors of V-type meter (vertical plane).

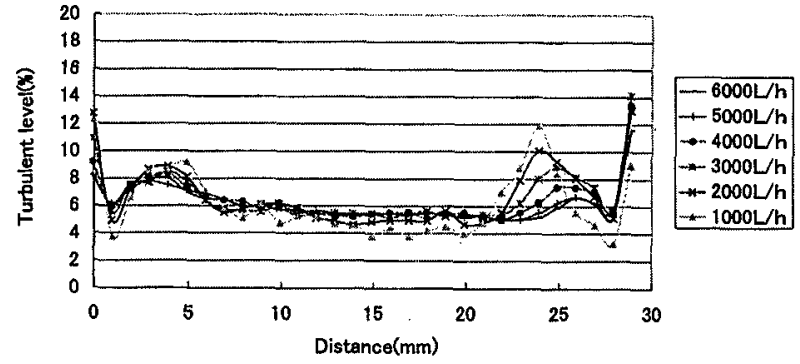

Fig13 Turbulent level of V-type meter.

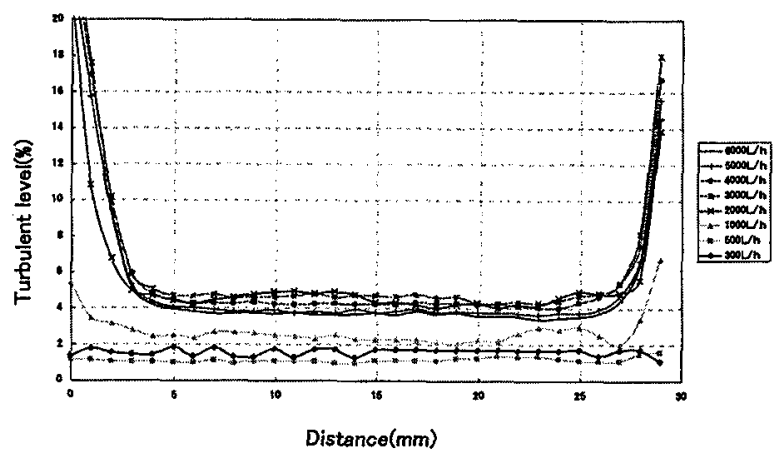

Fig. 15 Turbulent level of V-type meter with small honeycomb.

\section{4. 結論}

往路と復路での超音波の到達速度の時間差から，流れ の速度を求めて流量を推定する超音波流量計の開発にお いて，流れの観点から流路の考察を行った．超音波流路 だけでなく流れ場全体での渦発生を減らし乱流強度を減 少させる意味から，滑らかな境界をもつV 型が精度をあ げられることがわかった．ただし流量計としては流路の みならずセンサ特性，その電子回路等の要因がそれぞれ に重要な構成を担っており，総合的な設計が必要である.

\section{参考文献}

1）大島・高宮：可視化情報 21, Suppl. 1, 163-166 (2001).

2）大島・高宮：可視化情報 22, Suppl. 1, 123-126 (2002).

3）可梘化情報学会編：流れの可視化ハンドブック，朝倉書店 (1986). 